\title{
A pathology not be overlooked in blunt chest trauma: Analysis of 181 patients with bilateral pneumothorax
}

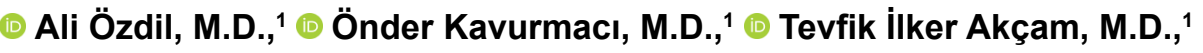 \\ (1) Ayşe Gül Ergönül, M.D., ${ }^{1}$ (1) İlhan Uz, M.D., ${ }^{2}$ (1) Cengiz Şahutoğlu, M.D., ${ }^{3}$

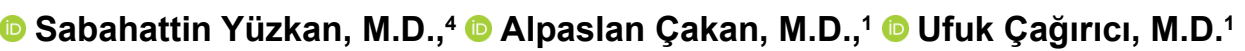

\author{
1'Department of Thoracic Surgery, Ege University Faculty of Medicine, İmir-Turkey \\ ${ }^{2}$ Department of Emergency Medicine, Ege University Faculty of Medicine, Izmir-Turkey \\ ${ }^{3}$ Department of Anesthesiology and Reanimation, Ege University Faculty of Medicine, İmir-Turkey \\ ${ }^{4}$ Department of Radiology, Ege University Faculty of Medicine, İmir-Turkey
}

\begin{abstract}
BACKGROUND: Bilateral pneumothorax (BPTx) can become tension PTx and a cause of mortality, especially in severe multi-trauma patients. The purpose of this study was to analyze the incidence, morbidity, mortality, and associated factors of BPTx in multi-trauma patients in order to highlight the importance of the management of these cases, as well as complications, morbidity, and mortality.

METHODS: The data of $18 \mathrm{I}$ patients with BPTx, from a total of 3782 trauma patients, were reviewed retrospectively. The details recorded were age, gender, mechanism of trauma, radiological findings, co-existing thoracic and extra-thoracic injuries, incidence of intubation, mortality, and injury severity score (ISS). The association between laterality of rib fracture, hemothorax, subcutaneous emphysema, and BPTx, and the effect of age and gender on these injuries, mortality, and ISS were analyzed.
\end{abstract}

RESULTS: The patient group included 144 males, and the mean age was $36.07 \pm 15.77$ years. The primary cause of trauma was a motor vehicle accident, seen in 67 (37.0\%) patients. Bilateral rib fractures were detected in 75 (4I.4\%) patients. Hemothorax accompanied PTx in $4 \mathrm{I}$ (22.6\%) patients bilaterally. The laterality of the rib fracture and hemothorax demonstrated a significant difference in the patient group over 60 years of age $(p=0.017, p=0.005)$. Co-existing bilateral thoracic injuries were detected more often in this group. Twelve (17.6\%) patients with only blunt chest trauma and $56(82.4 \%)$ patients with multi-trauma were intubated. The difference between the 2 groups was not significant $(p=0.532)$. The overall mortality rate was $18.2 \%$. A comparison of ISS and mortality between the groups revealed no significant difference $(p=0.22)$.

CONCLUSION: The incidence of BPTx after multi-trauma is approximately $5 \%$, so it must be taken into consideration, especially in severe multi-trauma patients, to reduce mortality. Older age and the number of rib fractures were determined to be risk factors for morbidity and mortality in trauma with BPTx.

Keywords: Bilateral pneumothorax; injury severity score; intubation; mortality; trauma.

\section{INTRODUCTION}

Chest trauma accounts for $10 \%$ to $15 \%$ of all traumas and is the leading cause of trauma death after brain injury, with a mortality rate up to $25 \%$. Blunt chest trauma (BCT) comprises $75 \%$ of chest trauma and the remainder is penetrating trauma. ${ }^{[1,2]}$
Pneumothorax (PTx) is a common and crucial consequence of BCT. It is a primary cause of mortality, so the diagnosis and management of PTx before fatal complications, such as tension PTx, can occur are important. ${ }^{[3]}$ In addition, bilateral PTX (BPTx), which is often misdiagnosed, especially in severe multi-trauma patients who have vital signs sufficiently stable to undergo radiological examination with a chest $\mathrm{X}$-ray or

Cite this article as: Özdil A, Kavurmacı Ö, Akçam Tí, Ergönül AG, Uz İ, Şahutoğlu C, et al. A pathology not be overlooked in blunt chest trauma: Analysis of 181 patients with bilateral pneumothorax. Ulus Travma Acil Cerrahi Derg 2018;24:521-527.

Address for correspondence: Ali Özdil, M.D.

Ege Üniversitesi Tıp Fakültesi, Göğüs Cerrahisi Anabilim Dalı, Bornova, İzmir, Turkey

Tel: +90 232 - 3904919 E-mail: ali.ozdil@ege.edu.tr

Ulus Travma Acil Cerrahi Derg 2018;24(6):52I-527 DOI: 10.5505/tjtes.2018.76435 Submitted: 09.07.2018 Accepted: 08.10.2018 Online: 25.10.2018

Copyright 2018 Turkish Association of Trauma and Emergency Surgery 
a thorax computed tomography (CT) in the early period of admission to emergency room, is a cause of mortality, just like tension PTx.

Rib fracture is the main cause of PTx and hemothorax in BCT, but it is not a requirement for the development of these complications. The incidence of PTx and hemothorax is approximately $35 \%$ in trauma patients with rib fractures. ${ }^{[1]}$

The aim of this study was to review the results of the clinical course of multi-trauma patients with BPTx first managed in the emergency room and followed up until discharge from the hospital in order to analyze the incidence, morbidity, and mortality of BPTx in multi-trauma patients with BCT in order to point out the importance of the management, prevention of complications, morbidity, and mortality. To the best of our knowledge, this study is one of the largest series in the English-language medical literature evaluating traumatic BPTx.

\section{MATERIALS AND METHODS}

The data of 3782 multi-trauma patients admitted to the emergency room between January 2010 and December 2017 were retrospectively reviewed, and the records of $18 \mathrm{I}$ (4.78\%) patients with BPTx were analyzed. The patient data were evaluated according to gender, age, mechanism of trauma, radiological findings, co-existing extra-thoracic injuries, treatment methods, length of hospital stay, mortality, and injury severity score (ISS).

All of the patients were first evaluated in the emergency room and initial treatment was performed there. The diagnosis of BPTx was performed with CT in patients with stable vital signs, which is routinely used for all multi-trauma patients as a part of the traumatic patient assessment algorithm. Bilateral thoracentesis was performed in unstable patients who were suspicious for BPTx as a result of physical examination findings, such as the absence of breath sounds or a finding of bilateral subcutaneous emphysema. All of the patients underwent a thorax CT after normalization of vital signs. Patients without any extrathoracic injury were hospitalized in the thoracic surgery department. Other patients with extrathoracic injury or an intubation requirement were followed up in the emergency room and the intensive care unit (ICU).

Data management and analysis of the study data was performed using IBM SPSS Statistics for Windows, Version 23.0. (IBM Corp., Armonk, NY, USA). The Kolmogorov-Smirnov test was used to assess data distribution. Continuous variables were summarized as mean $\pm S D$. Categorical data were presented as percentages and compared using the Fisher exact test for 2 groups and the Pearson chi-squared test for $>2$ groups. Student's t-test and the Mann-Whitney U-test were performed for data with normal and abnormal distribution, respectively. The statistical level of significance used was $\mathrm{p}<0.05$.
The present study was approved by the institutional ethics review panel. Patient consent for data collection was not required.

\section{RESULTS}

A total of 181 patients with a mean age of $36.07 \pm 15.77$ years (range: 16-84 years) were included. Of the group, 144 were male. The main cause of trauma was a motor vehicle accident, observed in 67 (37.0\%) patients, followed by a fall (22.1\%), and a motorcycle accident (18.8\%) (Fig. I). Descriptive data of the patient demographics are provided in Table I. Subcutaneous emphysema was the most common physical examination finding, observed bilaterally in 42 (23.2\%) patients. Rib fractures were detected in 127 (70.1\%) patients on thorax CT and 75 (4I.4\%) of these were bilateral; no rib fractures were detected in 54 (29.8\%) patients. PTx was accompanied by hemothorax in $7 \mathrm{I}(39.2 \%)$ patients and $4 \mathrm{I}$ (22.6\%) of these were bilateral (Fig. 2). Pneumomediastinum and sternum fracture were observed in 43 (23.8\%) and 19 (10.5\%) patients, respectively. A tube thoracostomy under local anesthesia was the most common invasive procedure performed for treatment. Twenty-seven (14.9\%) patients underwent tube thoracostomy bilaterally, whereas 103 (56.9\%) patients were kept under observation without any invasive procedures. The duration of the tube thoracostomy ranged from 5 to 16 days in patients with a bilateral drain.

Two groups of patients were formed, divided according to age of $\leq 60$ and $>60$ years, and the groups displayed a significant difference in terms of the laterality of rib fracture, the number of rib fractures, and the laterality of hemothorax, with $p$ values of $0.017,0.017$, and 0.005 , respectively. These co-existing thoracic pathologies were seen bilaterally more frequently in the group of patients over 60 years of age. The mortality was also significantly higher in this patient group $(p=0.013$; Table 2). There was no significant difference between males and females according to the co-existing thoracic pathologies, ISS, intubation, need for mechanical ventilation (MV), or mortality (Table 3).

The analysis of the association between the number of rib fractures and co-existing thoracic pathologies revealed a sig-

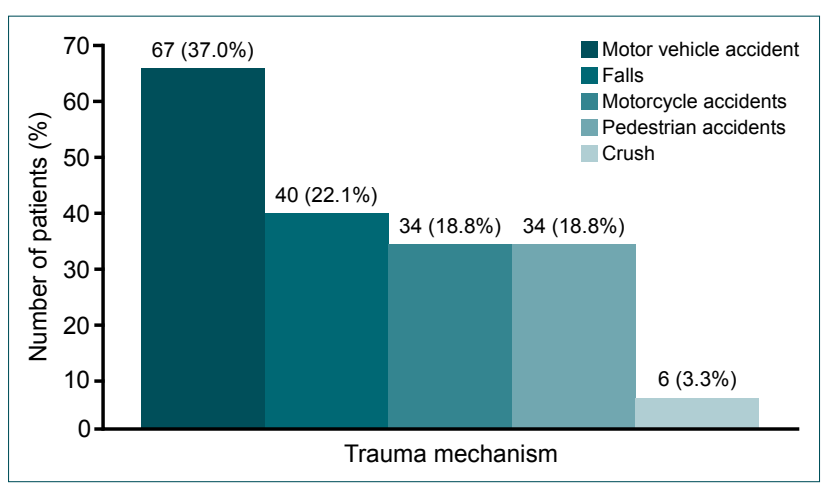

Figure 1. Distribution of patients based on trauma mechanism. 
Table I. Distribution of patient demographics, radiological findings, and results of clinical course

\begin{tabular}{|c|c|}
\hline & n (\%) \\
\hline Age (years) & $36.07 \pm 15.77$ \\
\hline \multicolumn{2}{|l|}{ Gender } \\
\hline Female & $37(20.4)$ \\
\hline Male & $144(79.6)$ \\
\hline \multicolumn{2}{|l|}{ Trauma } \\
\hline / Multi-trauma) & $28(15.5) / 153(84.5)$ \\
\hline \multicolumn{2}{|l|}{ Radiological findings } \\
\hline \multicolumn{2}{|l|}{ Subcutaneous emphysema } \\
\hline (None/Unilateral/Bilateral) & II $5(63.5) / 24(13.3) / 42(23.2)$ \\
\hline \multicolumn{2}{|l|}{ Rib fracture } \\
\hline (None/Unilateral/Bilateral) & $54(29.8) / 52(28.7) / 75(41.5)$ \\
\hline Hemothorax & $110(60.8) / 30(16.6) / 41(22.7)$ \\
\hline Pneumomediastinum & $43(23.8)$ \\
\hline Sternum fracture & $19(10.5)$ \\
\hline \multicolumn{2}{|l|}{ Tube thoracostomy } \\
\hline (None/Unilateral/Bilateral) & $103(56.9) / 51(28.2) / 27(14.9)$ \\
\hline Hospital stay (days) & $12.93 \pm 15.04$ \\
\hline Injury severity score & $26.69 \pm 6.11$ \\
\hline Mortality & $18.2 \%$ \\
\hline
\end{tabular}

nificant difference in the laterality of hemothorax when the patients were assessed in groups defined as having $\leq 6$ or $>6$ rib fractures (Table 3). Patients with more than 6 rib fractures had a higher incidence of bilateral hemothorax $(p<0.00 \mathrm{I})$ (Table 4).

Abdominal injuries, detected in 96 (53.0\%) patients, were the most common extrathoracic injury accompanying BCT, followed by vertebral injuries in 83 (45.9\%) patients and ex-

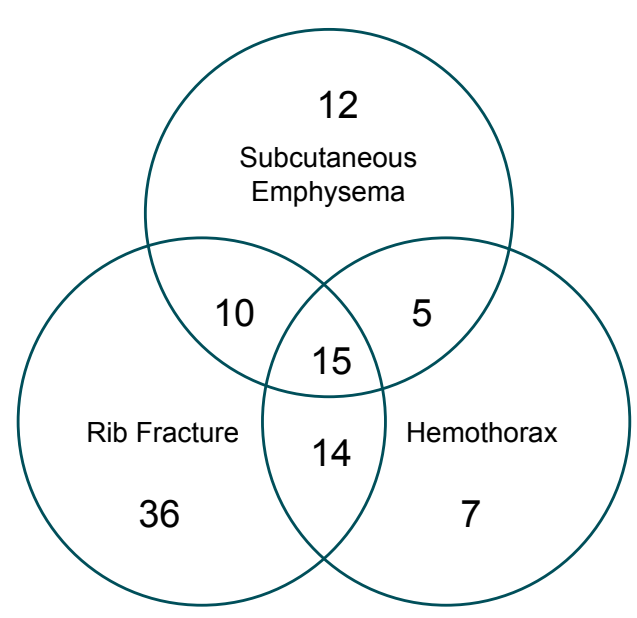

Figure 2. Distribution of bilateral co-existing thoracic injuries.
Table 2. The association between age, co-existing thoracic pathologies, tube thoracostomy insertion, injury severity score, intubation, and mechanical ventilation, and mortality

$\frac{\leq 60 \text { years }}{n(\%)} \frac{>60 \text { years }}{n(\%)} \quad p$

Subcutaneous emphysema

$\begin{array}{lcc}\text { Unilateral } & 23(12.7) & 1(0.6) \\ \text { None } & 100(55.2) & 15(8.3) \\ \text { Bilateral } & 33(18.2) & 9(5.0)\end{array}$

Rib fracture

$\begin{array}{llc}\text { Unilateral } & 45(24.9) & 7(3.9) \\ \text { None } & 52(28.7) & 2(1.1) \\ \text { Bilateral } & 59(32.6) & 16(8.8)\end{array}$

0.137

No. of rib fractures

$\begin{array}{llc}\leq 6 & 97(53.6) & 9(5.0) \\ >6 & 59(32.6) & 16(8.8)\end{array}$

Hemothorax

$\begin{array}{lcc}\text { Unilateral } & 24(13.2) & 6(3.3) \\ \text { None } & 102(56.4) & 8(4.4) \\ \text { Bilateral } & 30(16.6) & 11(6.1)\end{array}$

Tube thoracostomy

$\begin{array}{lcc}\text { Unilateral } & 47(26.0) & 4(2.2) \\ \text { None } & 87(48.1) & 16(8.8) \\ \text { Bilateral } & 22(12.2) & 5(2.8)\end{array}$

njury severity score

$\begin{array}{lcc}\leq 18 & 23(12.7) & 5(2.8) \\ >18 & 133(73.5) & 20(11)\end{array}$

0.500

Intubation and

mechanical ventilation

\begin{tabular}{lccc} 
Yes & $58(32.0)$ & $10(5.5)$ & 0.787 \\
No & $98(54.2)$ & $15(8.3)$ & \\
ortality & & & \\
Alive & $132(72.9)$ & $16(8.8)$ & 0.013 \\
Exitus & $24(13.3)$ & $9(5.0)$ & \\
\hline
\end{tabular}

tremity fractures in 79 (43.6\%) patients (Fig. 3). Seventy-eight (43.1\%) patients were treated and managed in the emergency room and 35 (19.3\%) patients were hospitalized in the thoracic surgery clinic. Patients requiring intubation and $M V$ were referred to the ICU and followed up there. A total of 68 (37.6\%) patients were intubated and monitored in the ICU. Twelve (17.6\%) of these patients had only BCT and 56 (82.4\%) had multi-trauma. There was no significant difference between the 2 groups in terms of intubation and MV $(p=0.532)$.

The overall mortality rate was $18.2 \%$ (33 patients), $97.0 \%$ (32 patients) of which was observed in the group of patients 
Table 3. The association between gender, co-existing thoracic injuries, tube thoracostomy insertion, ISS, intubation, and mechanical ventilation, and mortality

\begin{tabular}{|c|c|c|c|}
\hline & Male & Female & $\mathbf{p}$ \\
\hline & n (\%) & n (\%) & \\
\hline \multicolumn{4}{|c|}{ Subcutaneous emphysema } \\
\hline Unilateral & $19(10.5)$ & $5(2.8)$ & 0.139 \\
\hline None & $96(53.0)$ & $19(10.5)$ & \\
\hline Bilateral & $29(16.0)$ & $13(7.2)$ & \\
\hline \multicolumn{4}{|l|}{ Rib fracture } \\
\hline Unilateral & $42(23.2)$ & $10(5.5)$ & 0.820 \\
\hline None & $44(24.3)$ & $10(5.5)$ & \\
\hline Bilateral & $58(32.0)$ & $17(9.4)$ & \\
\hline \multicolumn{4}{|c|}{ No. of rib fractures } \\
\hline$\leq 6$ & $86(47.5)$ & $20(11.0)$ & 0.577 \\
\hline$>6$ & $58(32.0)$ & $17(9.4)$ & \\
\hline \multicolumn{4}{|l|}{ Hemothorax } \\
\hline Unilateral & $25(13.8)$ & $5(2.8)$ & 0.814 \\
\hline None & $86(47.5)$ & $24(13.3)$ & \\
\hline Bilateral & $33(18.2)$ & $8(4.4)$ & \\
\hline \multicolumn{4}{|c|}{ Tube thoracostomy } \\
\hline Unilateral & $42(23.2)$ & $9(5.0)$ & 0.766 \\
\hline None & $80(44.2)$ & $23(12.7)$ & \\
\hline Bilateral & $22(12.2)$ & $5(2.8)$ & \\
\hline \multicolumn{4}{|c|}{ Injury severity score } \\
\hline$\leq 18$ & $22(12.2)$ & $6(3.3)$ & 1.000 \\
\hline$>18$ & $122(67.4)$ & $31(17.1)$ & \\
\hline \multicolumn{4}{|l|}{ Intubation and } \\
\hline \multicolumn{4}{|c|}{ mechanical ventilation } \\
\hline Yes & $50(27.6)$ & $18(9.9)$ & 0.131 \\
\hline No & 94 (51.9) & $19(10.5)$ & \\
\hline \multicolumn{4}{|l|}{ Mortality } \\
\hline Alive & II 17 (64.6) & $31(17.1)$ & 0.815 \\
\hline Exitus & $27(14.9)$ & $6(3.3)$ & \\
\hline
\end{tabular}

who were intubated. The remaining 148 (8I.8\%) patients were discharged from the hospital with a mean hospital stay of $12.93 \pm 15.04$ days (range: $1-120$ days). There was no significant difference between the isolated thorax trauma patients and the multi-trauma patients in terms of mortality $(p=0.331)$. The survival analysis also revealed no significant difference between these 2 groups $(p=0.299)$.

The mean ISS was found to be $26.69 \pm 6$.II (range: I8-4I). A comparison between ISS and mortality yielded no significant difference $(p=0.22)$. The median ISS score was 26 (min-max: $21-29)$ in the patients who died and 26 (min-max: $21-33$ ) in the discharged patients. No significant association was deter-
Table 4. The association between the number of rib fractures, co-existing thoracic injuries, and tube thoracostomy insertion

\begin{tabular}{|c|c|c|c|}
\hline & $\leq 6$ & $>6$ & $\mathbf{p}$ \\
\hline & n (\%) & n (\%) & \\
\hline \multicolumn{4}{|c|}{ Subcutaneous emphysema } \\
\hline Unilateral & $20(11.0)$ & $4(2.2)$ & 0.139 \\
\hline None & $69(38.1)$ & $46(25.4)$ & \\
\hline Bilateral & $17(9.4)$ & $25(13.8)$ & \\
\hline \multicolumn{4}{|l|}{ Hemothorax } \\
\hline Unilateral & $19(10.5)$ & II (6.I) & $<0.001$ \\
\hline None & $75(41.4)$ & $35(19.3)$ & \\
\hline Bilateral & $12(6.6)$ & $29(16.0)$ & \\
\hline \multicolumn{4}{|c|}{ Tube thoracostomy } \\
\hline Unilateral & $27(14.9)$ & $24(13.3)$ & 0.097 \\
\hline None & $67(37.0)$ & $36(19.9)$ & \\
\hline Bilateral & $12(6.6)$ & $15(8.3)$ & \\
\hline
\end{tabular}

mined between ISS and intubation and MV ( $p=0.275)$ : the median ISS score was 27.5 (min-max: 2I-34) and 26 (min-max: 21-29) for intubated and non-intubated patients, respectively. The patients were also divided into 2 groups according to an ISS of $\leq 18$ or $>18$. No difference was seen between the groups according to intubation and mortality $(p=0.532$ and $p=0.299)$.

\section{DISCUSSION}

BCT is a frequent cause of morbidity and mortality, especially in developing countries. The primary cause of BCT is motor vehicle and other traffic accidents, with an incidence rate reported in various studies that has ranged from $47.5 \%$

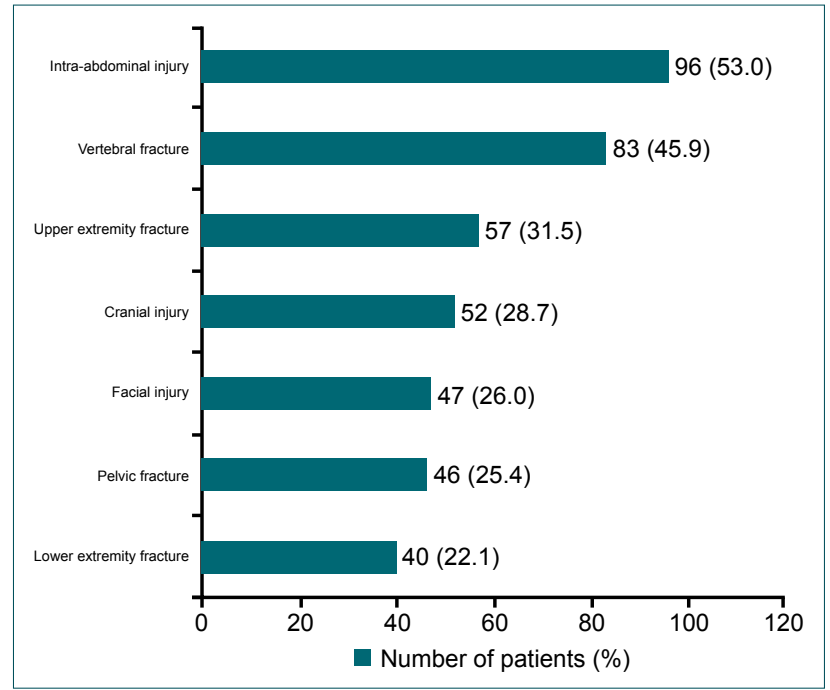

Figure 3. Co-existing extra-thoracic injuries of patients with multitrauma. 
to $70.9 \%{ }^{[2,4-6]}$ The incidence of motor vehicle accidents was $37.0 \%$ in our study, but with the addition of motorcycle and pedestrian accidents, the total was $74.6 \%$, which is consistent with that seen in the literature.

Rib fracture may be both the result of BCT and the cause of thoracic pathologies like pain, contusion, PTx, and hemothorax. Cases of multiple rib fractures accompanying multitrauma have particularly been determined to be a prognostic factor of morbidity and mortality. ${ }^{[7]}$ The incidence of rib fracture in all trauma cases varies in the range of $10 \%$ to $40 \%$. [1,4] Chrysou et al. ${ }^{[8]}$ reported that rib fractures comprised the largest group of thoracic injuries, with a rate of $86.4 \%$. The incidence of bilateral rib fractures has been reported to be $22.7 \%$. Sirmali et al. ${ }^{[2]}$ reported that PTx, hemothorax, or hemopneumothorax had been noted in $72.3 \%$ of the cases with rib fractures. Liman et al. ${ }^{[6]}$ stated an incidence rate of $52 \%$ hemo-/pneumothorax in patients with rib fractures. These 2 studies did not report the incidence rate of BPTx. In our study, the incidence of rib fractures was $70.1 \%$, and $41.4 \%$ of these were bilateral. On the other hand, we did not detect rib fractures in $29.8 \%$ of the patients. This result was an important indicator of whether the major reason for PTx, especially BPTx, is related to rib fractures. Rib fractures may not be present in approximately one-third of patients; therefore, patients must be evaluated and followed up very closely after an initial intervention, even when there are no rib fractures or evident PTx. Lu et al. ${ }^{[9]}$ reported the late onset of PTx during the first 2 days of admission with an incidence rate of $5.42 \%$ in trauma patients with minor rib fractures. Furthermore, Shorr et al. ${ }^{[4]}$ found 44 (34.6\%) cases of hemopneumothorax in 127 patients without bony thoracic injury.

Pneumothorax is a serious potential consequence of BCT that is life-threatening and requires immediate diagnosis and treatment. While a chest X-ray is usually sufficient to detect PTx, a thorax CT is usually needed in multi-trauma patients who cannot be positioned adequately for posteroanterior chest X-ray imaging. The frequency of PTx in BCT patients is approximately $15 \%$ to $20 \% .^{[4,10,11]}$ Bilateral PTx is a more serious and complicated scenario that can be overlooked in BCT patients with multi-trauma. Shorr et al. ${ }^{[4]}$ reported 15 instances of BPTx in 515 BCT patients, a rate of $2.9 \%$. Freixinet et al. ${ }^{[2]}$ conducted a study that included 1772 patients with chest trauma, and the incidence rate of BPTx was reported as $1.3 \%$. Sunam et al. ${ }^{[13]}$ described 40 patients with BPTx and mentioned that 25 cases were due to BCT. Halat et al. ${ }^{[14]}$ reported that the incidence rate of BPTx in their study of 110 blunt chest trauma patients was $17.3 \%$. In our study, the incidence rate of BPTx was $4.78 \%$ ( 181 patients among 3782). There are few studies specifying the incidence rate of BPTx in the literature and the incidence rate was a bit higher in our research results compared with most of the previously-mentioned studies. This difference may be associated with the method of initial imaging. All of our patients underwent thorax CT for the evaluation of thoracic injuries, which might have yielded a determination of minor PTx that could not be seen on a chest X-ray or had not led to clinical symptoms and findings.

Age is a risk factor for the severity and complication of trauma. In elderly patients, multiple and bilateral rib fractures are seen more frequently, even in a moderate trauma, due to the osteoporosis and fragility of the bones. Therefore, the incidence of complications, like BPTx and hemothorax, as well as mortality, is higher in elderly trauma patients. ${ }^{[2,15,16]}$ Sirmali et al. ${ }^{[2]}$ reported that the highest morbidity and mortality rates were found in patients over the age of 60 years and mentioned that elderly patients with 6 or more rib fractures must be followed up in the ICU. Bulger et al. ${ }^{[15]}$ stated that elderly patients had twice the rate of mortality and morbidity of younger patients with injuries of similar severity. In our study, co-existing thoracic pathologies and mortality were higher in the patient group that was over 60 years of age. This finding indicates that elderly patients must be evaluated and followed up more intensively, independent of the severity of the trauma.

Extra-thoracic injuries frequently accompany BCT in multitrauma patients. Common associated injuries include spine injuries, extremity fractures, abdominal injuries, and head trauma. ${ }^{[1]}$ In the study conducted by Chrysou et al., ${ }^{[8]}$ the most common co-existing extra-thoracic injuries were extremity fractures, spine injuries, and head trauma, with an incidence rate of $76.4 \%, 53.6 \%$, and $37.3 \%$, respectively. Freixinet et al. ${ }^{[12]}$ reported a rate of $19.1 \%$ for extra-thoracic trauma, and mentioned that limb fracture was the most common pathology, with an incidence of $28.7 \%$. Hildebrand et al. ${ }^{[18]}$ stated that injuries to the extremities were the most frequently associated injuries, independent of the severity of the thoracic injury. In their study composed of 1621 thoracic trauma patients, Lin et al. ${ }^{[19]}$ also reported that extremity fractures were the most common $(26.7 \%)$ associated injury accompanying traumatic rib fractures. The incidence rate of extra-thoracic injuries was $84.5 \%$ in our study. Abdominal injuries, including liver, spleen, and kidney pathologies, were the most common injuries at $53 \%$, followed by vertebral fractures (45.9\%). In contrast to the literature, extremity fractures were the third most frequently observed extra-thoracic injury in our research, with an incidence rate of $43.6 \%$. We think that this divergence was related to the inclusion of trauma patients who were sent from other hospitals due to the severity of the trauma, as our hospital has the biggest and most experienced trauma center in the region.

Intubation and $\mathrm{MV}$ are indicators of a poor prognosis in trauma patients. In multi-trauma patients, especially those with head and bilateral chest injuries, the incidence rate of intubation and $M V$ is higher. The length of stay in the ICU is also typically longer in these patients. The incidence rate of intubation and $\mathrm{MV}$ was reported as $6.9 \%$ in 1772 trauma cases by Freixinet et al. ${ }^{[12]}$ and was stated to be a poor prog- 
nostic factor for multiple injury and cardiorespiratory repercussions. Virgós Señor et al. ${ }^{[20]}$ noted that MV was a significant factor for death in BCT patients and reported an incidence rate of $81.5 \%$ in 108 multi-trauma patients. The authors did not report any significant differences in terms of multiple trauma, head/brain injury, or PTx between the patients who did and did not require MV. They also indicated that PTx was a significant factor for survival in patients with MV. Charbit et al. ${ }^{[3]}$ reported that $47.0 \%$ of patients with PTx after BCT were intubated and followed up with MV. Chrysou et al. ${ }^{[8]}$ reported that intubation and MV had been necessary for 29.1\% (32 in I 10 patients) of polytrauma patients with BCT. In our study, the incidence rate of intubation and $M V$ was $37.6 \%$. While this rate is in the range of the 4 studies mentioned above, it was higher than that of 3 of the mentioned studies. This may be due to the fact that all of the patients in our study had BPTx. Virgós Señor et al. ${ }^{[20]}$ reported a higher incidence rate than that of our study, which may have been because their study included trauma patients in an ICU. Furthermore, there was not a significant difference between the isolated BCT and the multi-trauma patients groups in our study, but the mortality rate was significantly higher in the intubated patient group, which is also consistent with the literature.

The overall mortality in polytrauma patients with BCT varies between $2.4 \%$ and $33.3 \% .^{[2,4-8,11,12,18-21]}$ The factors associated with survival include the severity of the BCT and co-existing injuries, especially neurotrauma. ${ }^{[8,21]} \mathrm{Di}$ Bartolomeo et al. ${ }^{[1]}$ reported an overall mortality rate of $23.3 \%$ in their study comprising 446 major trauma patients. They reported a mortality rate that increased to $30.4 \%$ in patients with PTx. Virgós Señor et al. ${ }^{[20]}$ mentioned that mortality had occurred all in patients in need of MV and reported that they had not seen a higher mortality rate among polytrauma patients in their studies, even those with head and brain injury. Chrysou et al. ${ }^{[8]}$ reported an overall mortality rate of $5.5 \%$ (6 in 110 patients) and stated that there was a significant association between mortality rate and ISS, as all 6 deaths were in the group with an ISS $>24$. Liman et al. ${ }^{[6]}$ and Hasbahçeci et al. ${ }^{[17]}$ also noted that mortality increased with an increasing ISS. Segers et al. ${ }^{[2]]}$ reported an overall mortality rate of $16.6 \%$ and an average ISS of 27.8 in their study that included 187 cases of thoracic trauma. They found a significant relationship between ISS and mortality, and reported that ISS was a valuable score for assessing the severity of trauma and predicting the outcome. In our study, the overall mortality rate was $18.2 \%$, and $97 \%$ of those patients were in the intubated patient group. The difference between the isolated thorax trauma patients and multi-trauma patients was not significant in terms of mortality, a finding similar to the result obtained in the study of Virgós Señor et al. ${ }^{[20]}$ We found that the mortality rate increased when the hospital stay was shorter. This difference may be related to the fact that most of the deaths occurred in the early period of admission due to fatal pathologies such as brain injury. There were no significant relationships between ISS and mortality in our study, contrary to the studies cited. We think that this was likely due to the fact that there was a minimum ISS score of 18 in the BPTx patients.

\section{Limitations}

There are some limitations to this study that should be kept in mind. This is a retrospective and single-center study, which results in a certain weakness of methodology and limited ability to generalize the result to other centers or circumstances. Also, because of the retrospective design of the study and missing data, it was not possible to specify the exact cause of mortality, especially in multi-trauma patients. As a result of this shortcoming, detailed survival analysis with respect to BPTx could not be performed.

\section{Conclusion}

In conclusion, pneumothorax is a life-threatening complication of BCT and it can be more complicated when it is bilateral. The rate of mortality caused by PTx in BCT is not clear in the literature. The available data are very limited, especially regarding BPTx after BCT. The mortality rate of $18.2 \%$ and the intubation incidence rate of $37.6 \%$ in our study point to the importance of diagnosis, management, and treatment of BPTx in BCT patients and the need for further studies about PTx and BPTx in multi-trauma patients. In addition, age must be kept in mind as a risk factor for morbidity and mortality independent of the severity of the trauma.

Funding: No funding was received for this work.

Conflict of interest: None declared.

\section{REFERENCES}

1. Ziegler DW, Agarwal NN. The morbidity and mortality of rib fractures. J Trauma 1994;37:975-9. [CrossRef]

2. Sirmali M, Türüt H, Topçu S, Gülhan E, Yazici U, Kaya S, et al. A comprehensive analysis of traumatic rib fractures: morbidity, mortality and management. Eur J Cardiothorac Surg 2003;24:133-8. [CrossRef]

3. Charbit J, Millet I, Maury C, Conte B, Roustan JP, Taourel P, et al. Prevalence of large and occult pneumothoraces in patients with severe blunt trauma upon hospital admission: experience of 526 cases in a French level 1 trauma center. Am J Emerg Med 2015;33:796-801. [CrossRef]

4. Shorr RM, Crittenden M, Indeck M, Hartunian SL, Rodriguez A. Blunt thoracic trauma: analysis of 515 patients. Ann Surg 1987;206:200-5.

5. Demirhan R, Onan B, Oz K, Halezeroglu S. Comprehensive analysis of 4205 patients with chest trauma: a 10-year experience. Interact Cardiovasc Thorac Surg 2009;9:450-3. [CrossRef]

6. Liman ST, Kuzucu A, Tastepe AI, Ulasan GN, Topcu S. Chest injury due to blunt trauma. Eur J Cardiothorac Surg 2003;23:374-8. [CrossRef]

7. Esme H, Solak O, Yürümez Y, Yavuz Y. The factors affecting the morbidity and mortality in chest trauma. Ulus Travma Acil Cerrahi Derg 2006;12:305-10.

8. Chrysou K, Halat G, Hoksch B, Schmid RA, Kocher GJ. Lessons from a large trauma center: impact of blunt chest trauma in polytrauma patientsstill a relevant problem? Scand J Trauma Resusc Emerg Med 2017;25:42. 
9. Lu MS, Huang YK, Liu YH, Liu HP, Kao CL.Delayed pneumothorax complicating minor rib fracture after chest trauma. Am J Emerg Med 2008;26:551-4. [CrossRef]

10. Weissberg D, Refaely Y. Pneumothorax: experience with 1,199 patients. Chest 2000;117:1279-85. [CrossRef]

11. Di Bartolomeo S, Sanson G, Nardi G, Scian F, Michelutto V, Lattuada L. A population-based study on pneumothorax in severely traumatized patients. J Trauma 2001;51:677-82. [CrossRef]

12. Freixinet J, Beltrán J, Rodríguez PM, Juliá G, Hussein M, Gil R, et al. Indicators of severity in chest trauma. [Article in Spanish]. Arch Bronconeumol 2008;44:257-62. [CrossRef]

13. Sunam G, Gök M, Ceran S, Solak H. Bilateral pneumothorax: a retrospective analysis of 40 patients. Surg Today 2004;34:817-21. [CrossRef]

14. Halat G, Negrin LL, Chrysou K, Hoksch B, Schmid RA, Kocher GJ. Treatment of air leak in polytrauma patients with blunt chest injury. Injury 2017;48:1895-9. [CrossRef]

15. Bulger EM, Arneson MA, Mock CN, Jurkovich GJ. Rib fractures in the elderly. J Trauma 2000;48:1040-6. [CrossRef]
16. Akköse Aydin S, Bulut M, Fedakar R, Ozgürer A, Ozdemir F. Trauma in the elderly patients in Bursa. Ulus Travma Acil Cerrahi Derg 2006;12:230-4.

17. Hasbahçeci M, Ozpek A, Başak F, Calışkan M, Ener BK, Alimoğlu O. Factors affecting mortality in blunt thoracic trauma. Ulus Travma Acil Cerrahi Derg 2013;19:127-32. [CrossRef]

18. Hildebrand F, Giannoudis PV, Griensven Mv, Zelle B, Ulmer B, Krettek $\mathrm{C}$, et al. Management of polytraumatized patients with associated blunt chest trauma: a comparison of two European countries. Injury 2005;36:293-302. [CrossRef]

19. Lin FC, Li RY, Tung YW, Jeng KC, Tsai SC. Morbidity, mortality, associated injuries, and management of traumatic rib fractures. J Chin Med Assoc 2016;79:329-34. [CrossRef]

20. Virgós Señor B, Nebra Puertas AC, Sánchez Polo C, Broto Civera A, Suárez Pinilla MA. Predictors of outcome in blunt chest trauma. [Article in Spanish]. Arch Bronconeumol 2004;40:489-94.

21. Segers P, Van Schil P, Jorens P, Van Den Brande F. Thoracic trauma: an analysis of 187 patients. Acta Chir Belg 2001;101:277-82.

\title{
ORIJIINAL ÇALIŞMA - ÖZET
}

\section{Künt gögüis travmasında gözden kaçırılmaması gereken bir patoloji:}

\section{Bilateral pnömotoraks saptanan 181 olgunun analizi}

\section{Dr. Ali Özdil, Dr. Önder Kavurmacı, Dr. Tevfik İlker Akçam, Dr. Ayşe Gül Ergönül, Dr. İlhan Uz,} Dr. Cengiz Şahutoğlu, Dr. Sabahattin Yüzkan, Dr. Alpaslan Çakan, Dr. Ufuk Çağırıcı

\author{
${ }^{1}$ Ege Üniversitesi Tıp Fakültesi, Göğüs Cerrahisi Anabilim Dalı, İzmir \\ 2Ege Üniversitesi Tıp Fakültesi, Acil Tıp Anabilim Dalı, İzmir \\ ${ }^{3}$ Ege Üniversitesi Tıp Fakültesi, Anesteziyoloji ve Reanimasyon Anabilim Dalı, İzmir \\ ${ }^{4}$ Ege Üniversitesi Tıp Fakültesi, Radyoloji Anabilim Dalı, İzmir
}

AMAÇ: Bilateral pnömotoraks (BPTx), özellikle şiddetli multi-travma hastalarında tansiyon PTx gibi mortalitenin önemli bir nedeni olabilir. Bu çalısmada, BPTx tedavisi ve buna bağlı komplikasyon, morbidite ve mortalitenin önemini belirtmek amacıyla multi-travma sonrası BPTx insidansı, morbidite, mortalite oranları ve bunlarla ilişkili faktörlerin analiz edilmesi amaçlandı.

GEREÇ VE YÖNTEM: Travma sonrası başvuran 3782 hastadan BPTx saptanan I8I hastanın verileri yaş, cinsiyet, travma çeşidi, radyolojik bulgular, eşlik eden torasik ve ekstra-torasik yaralanmalar, entübasyon insidansı, mortalite ve travma şiddet skoru (TŞS) açısından geriye dönük olarak analiz edildi. Kot kırı̆ıııı tarafı, hemotoraks, ciltaltı amfizemi ve BPTx arasındaki ilişki ile yaş ve cinsiyetin bu yaralanma, mortalite ve TŞS'ye etkisi araştııılı.

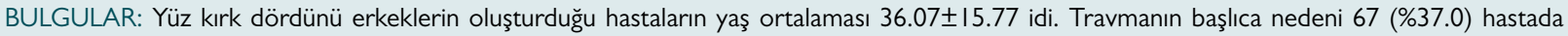
bildirilen araç-içi trafik kazasıydı. Yetmiş beş (\%4I.4) hastada iki taraflı kot kırı̆̆ı izlendi. Hastaların 4 I'inde (\%22.6) BPTx'a iki taraflı hemotoraks eşlik ettiği belirlendi. Özellikle 60 yaş üstü hasta grubunda kot kırı̆ı̆ ve hemotoraksın tarafı açısından anlamlı fark saptandı $(p=0.017, p=0.005)$. Bu hasta grubunda eşlik eden torasik yaralanmaların daha sık olarak iki taraflı olduğu belirlendi. İzole toraks travması olan 12 (\% I7.6) ve multi-travması olan 56 (\%82.4) hasta entübe edildi. İki grup arasında entübasyon açısından anlamlı fark bulunmadı ( $p=0.532)$. Toplam mortalite oranı \% 8.2 idi. Travma şiddet skoru ile mortalite arasında anlamlı bir ilişki saptanmadı $(p=0.22)$.

TARTIŞMA: Travma sonrasında BPTx insidansı yaklaşık olarak \%5 oranındadır; bu nedenle özellikle şiddetli travma sonrasında mortalite oranını azaltmak amacıyla BPTx akılda bulundurulması gereken bir patolojidir. Yaş ve kot kırı̆̆ı sayısı BPTx saptanan multi-travma hastalarında morbidite ve mortalite için risk faktörleridir.

Anahtar sözcükler: Entübasyon; iki taraflı pnömotoraks; mortalite; travma; travma şiddet skoru. 